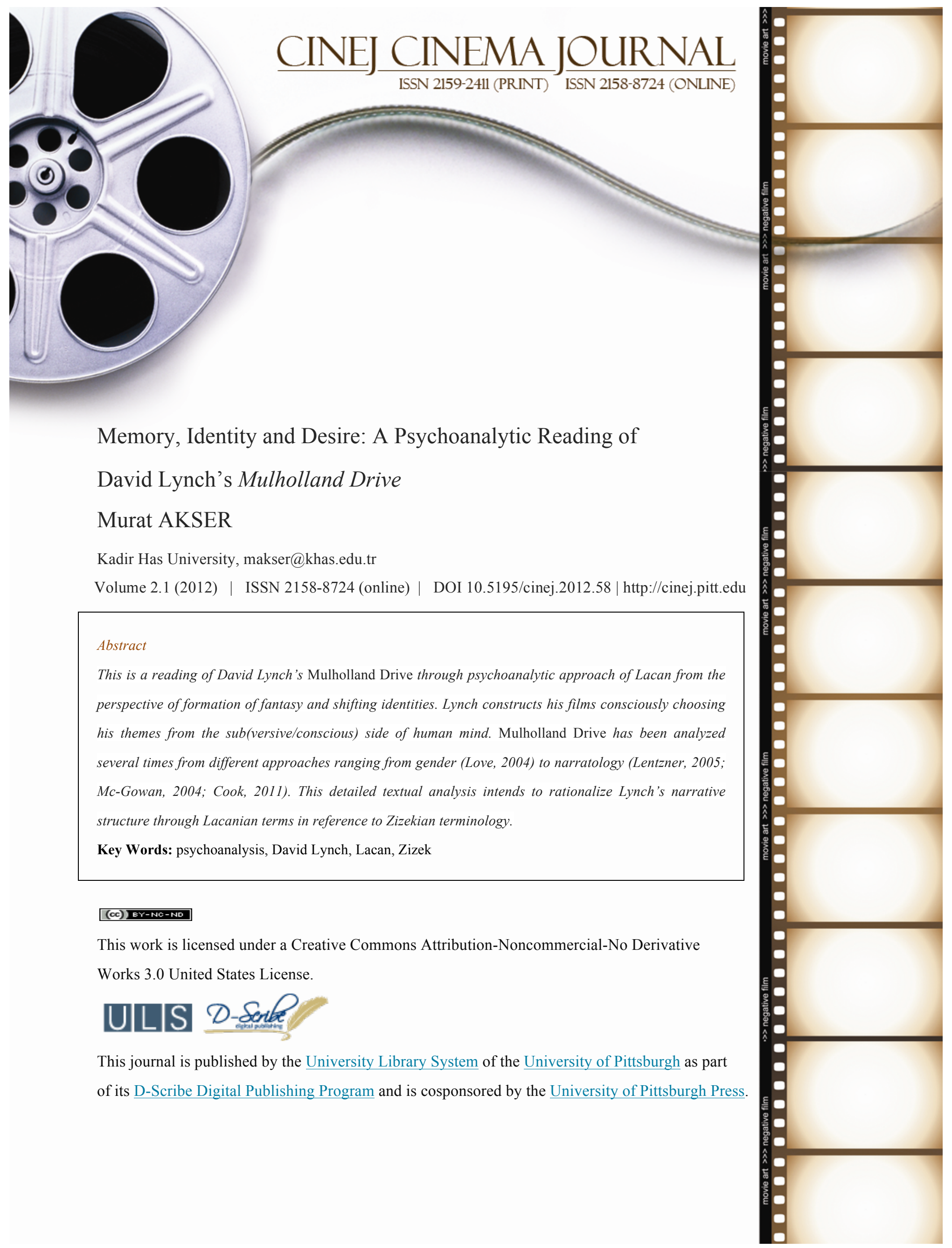




\section{Memory, Identity and Desire: A Psychoanalytic Reading of David Lynch's Mulholland Drive}

\section{Introduction $^{1}$}

Around and after 9/11, several films dealing with trauma and memory, and amnesia and identity were released. Winter Sleepers (Tom Tykwer, 1998), Memento (Christopher Nolan, 2001), Vanilla Sky (Cameron Crowe, 2001), The Bourne Identity (Doug Liman, 2002) and Inception (Christopher Nolan, 2010) are feature dramatic films about memory loss and how we define ourselves through the events, objects, sensations and perceptions that we remember (Tubrett, 2001). American avant-garde filmmaker David Lynch also made two strong contributions to this trend with his films Lost Highway (1998) and Mulholland Drive (2001). Lost Highway dealt with two men whose identities were linked as each other's alter egos in a Doppelganger story that paralleled the histories of two couples, one fantasy and the other real. In Lost Highway, memories and identities transcend bodies in choosing their host and eventually the fantasies collapse, free from the wills of the men who created them ${ }^{2}$.

A psychoanalytical approach is one possible way of reading the film. Lynch's characters are sadistic maniacs, murderers, and femme fatales, as well as the innocent boys who fall for them. All of these fit well within the Oedipal triangle of mother, son and the father. Since the 1970 s, theories of psychoanalysis have been adapted for cinema studies. Women and media, reception, and the ontology of the cinematic image were among the first areas to be scrutinized. The use of texts written by Freud and Lacan provided fresh perspectives for film theorists (Allen, 1999). The main focus of these theories was the integration of former approaches like semiotics and feminist film theory. Over time, however, psychoanalytic film theory was met with criticism from other disciplines and other branches within film studies. Just when the demise of psychoanalytic readings of film seemed imminent, the Slovenian thinker/philosopher Slavoj Zizek contributed to discourses on popular culture through an approach that combined philosophy, psychoanalysis and film (Zizek, 1991; 1992; 2001). Zizek's approach has been widely accepted, but it should be noted that novel ways of conducting film analysis emerged in the 2000s (Akser, 2011). 
Rather than using Lacan to explain cinematic processes as proposed by apparatus theory advocates, Zizek reads film texts according to the Lacanian concepts of the symbolic, imaginary and the Real (Zizek, 2002). His main focus is on the filmic text, the main universe of the object of analysis. Thus, as he treats film as it is, he is not distracted by discussions in film studies on such issues as realism, narrative linearity, representation and relation to life, including viewer participation. In 2000, Zizek gave a lecture at the University of Washington in Seattle on Lynch's Lost Highway. In this lecture, Zizek stressed the need to read Lynch in psychoanalytic terms (Zizek, $2000)^{3}$. Inspired by Zizek's reading of Lynch, this essay takes up a psychoanalytic reading of David Lynch's Mulholland Drive (2001) and also utilizes some classical Freudian principles as well. Psychoanalysis is largely concerned with the issue of subject formation. In other words, what cultural studies refer to as identity is implicated in subjectivity. Mulholland Drive is all about subjectivity and subject formation. Thus, taking repression of the unconsciousness into account is key to understanding the film.

\section{Mulholland Drive: An Identity Puzzle}

David Lynch has become a trademark name in innovation and the macabre. Mulholland Drive was a pilot for a television drama series for the ABC network in the tradition of Lynch's previous TV series Twin Peaks. After being rejected by the TV network and stretched to the limits, it was released as a feature film with multiple characters and their complicated relationships. As regards the film, the word "drive" cuts two ways. It is the title of the street where the accident occurs as well as the symbolic "death drive" or "sex drive."

Mulholland Drive begins with a young woman miraculously escaping from a car crash in a limousine where armed men were trying to kill her. The young woman, who is in shock, walks down to Beverly Hills and spends 
the night on a lawn. At the break of dawn, she wakes up and notices an old woman leaving her home, and she sneaks into the housing complex. Just then Betty Elms (Naomi Watts) arrives. Betty is a young blond woman from Deep River, Ontario who came to Hollywood to be a movie star. Betty's aunt and uncle own the house which the mystery woman sneaks into. Betty had moved into this house in Beverly Hills. Soon Betty notices the mysterious young brunette in her aunt's house. This woman does not remember anything about her past or who she is. Inspired by a poster in the washroom, the woman says that her name is Rita (the poster is of Gilda, Rita Hayward). After searching her bag they find a large amount of money and a mysterious blue key. Rita settles in Betty's house and the two begin searching for Rita's past.

In the meantime a young film director, Adam Kesher, is struggling to make a musical but is not allowed to cast the main actress because of threats from the mob, the Castigliani Brothers (castration), who are controlled by an enigmatic boss, Mr. Roque. Although Adam tries to resist these demands, he realizes that the mob seized his money in the bank and shut down the production company's operations, and they threaten to kill him if he does not cast Camille Rhodes, a woman he has never met, for the main role. The film project gets cancelled and his wife leaves him, and so Adam gives up and agrees. Meanwhile Betty goes to an audition and is offered a first contract. Her ambition to star in a film leads her to Adam's set and she comes eye to eye with him. But she has to leave without auditioning for the main role because she had promised to help Rita find her identity. After meeting Rita, the two go to a house where Rita's friend (Diane Sullivan) may live and they meet Diane's former housemate. They break into Diane's house and discover her dead body. At the end of this stressful day, the two have sex in bed. After midnight, Rita speaks in a dream and utters the words "El Silencio." The clues lead them to a Spanish nightclub where, during a performance, Betty takes out a blue box from her bag. When Rita goes back home and inserts the key in the box, time-space-reality is transformed. This is the end of narrative segment one (S1) (or Fantasy level 2-F2). 
In segment two (S2), we see that Betty is now Diane Sullivan. In this segment, Diana is left by her lesbian lover housemate and dreams of a Camilla Rhodes in her place in a fantasy (F-1). In this fantasy, she is a struggling actress whose aunt dies and leaves her money to live in LA. After failing to get a role, Diane meets Rita and the two become lovers. Rita becomes the lead actress in Adam's new film. That night the two get in a limousine and then their car stops at the party of a film director, who is named Adam. Adam is happy to have an affair with Camilla and takes pleasure in showing her success and making Diane jealous. Adam announces that he and Camilla are going to do something that ambiguously sounds like a marriage proposal. In exchange, Camilla gets a role for Dianne. In anger, Diane hires an assassin (we are not absolutely sure if that is the case) giving Camilla's photo and money. In and out of this fantasy in the final scene of the film Diane goes crazy, seeing demons and Betty's uncle and aunt shouting with demonic voices.

\section{The Characters and Their Complexes}

The film is clearly divided into two segments, which I chronologically refer to as S1 (pre-transformation) and S2 (after Betty is seen as Diane). In S1, Betty, Rita and Adam try to survive in Hollywood. This segment is the deeper fantasy situated inside Diane Sullivan's first fantasy connected through the blue box and the key. In S2, in the first fantasy Diane is the loser whereas Adam and Rita are the winners. From a narrative textual reading, the film can be read in two ways: Either the naive Betty meets a lost Rita and the two enter a miraculous time-space distortion where the past becomes the future, connecting a present in which both Betty and Rita shift identities/positions. Or the second segment could signify the first segment as a "fantasy" in which Diane, feeling desperate after the loss of her lesbian housemate-lover, first fantasizes about the more beautiful and amorous lover Camille Rhodes who betrays her. In return, to punish her and the others who mistreat her in her first fantasy, she recreates herself as a naïve, sexy Canadian (Betty) in the second deeper fantasy embedded within her first fantasy. In this inner fantasy, Betty takes charge of things, manages a lost (Camille now turned into) Rita and is successful. My analysis focuses 
on this first reading, which is useful approach for film scholars interested in trans-genre bending, the relationships between narrative and space-time and meta-narrative frame-stories.

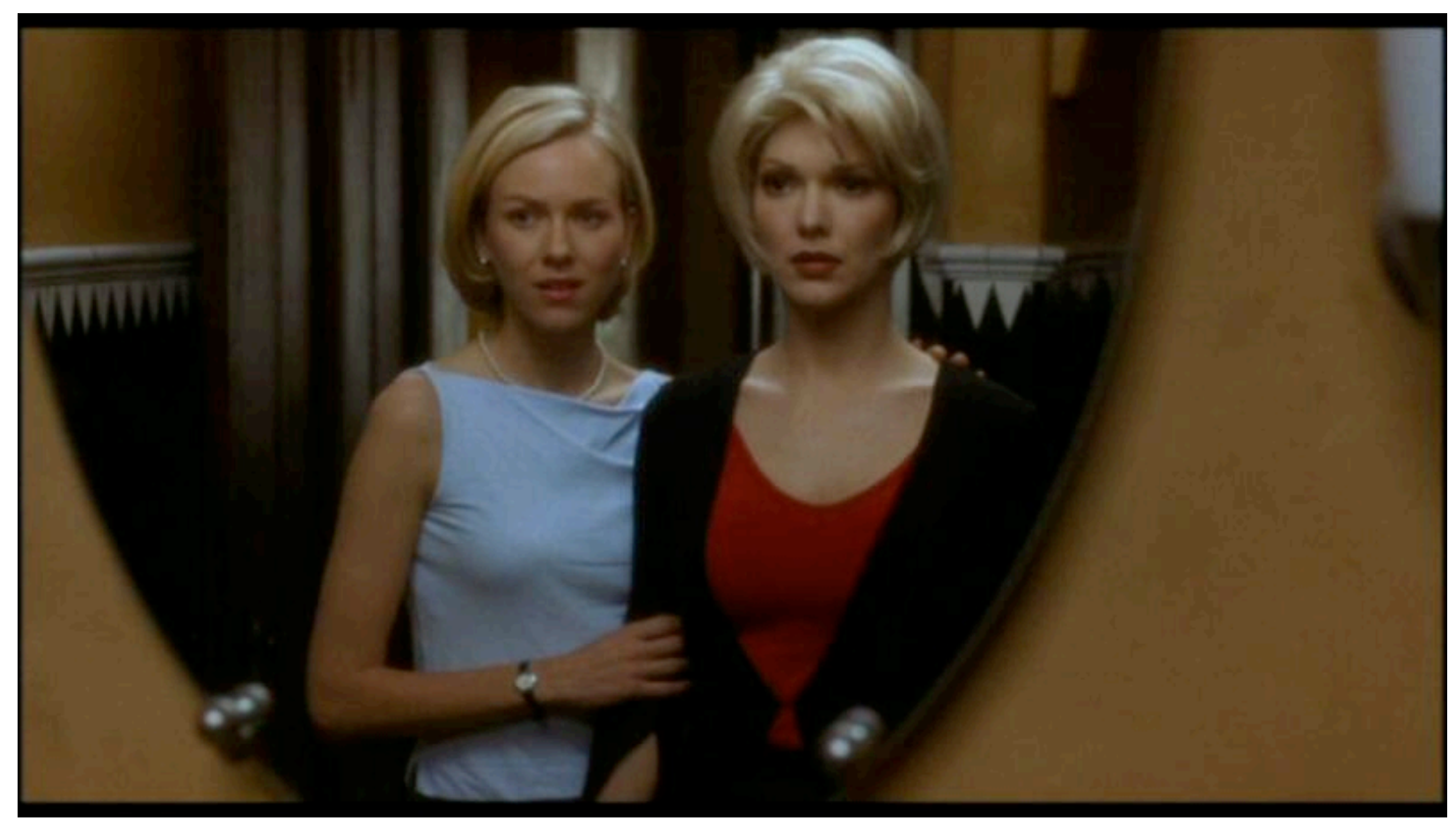

Figure 1: Diane/Betty wants to be successful and in a reverse fantasy she gets to shape success as the other (Camille/Rita) to herself.

\section{The Three Women: Elements of Fantasy}

If we take Diane Sullivan as the source of these two fantasies and part of the second segment as the framework for reality, we can say that Diane's repressed unconscious resurfaces in both fantasy segments. In S2, Diane's reality is bleak. She is a loser, and her face and body have lost its freshness. Her lover Camille can manage both Diane and have sexual relationships with Hollywood figures to achieve her ends. Camille gets the lead role in Adam's film and through Camille's intervention, Diane only gets a minor role. Camille also does everything to make Diane jealous, such as flirting with Adam. After being left by her real life (anonymous) lover, Diane's Camille fantasy realistically reflects all her needs. She is not good-looking or dominant, and of course an amorous lover will bring her somewhere but she will pay the price by losing her to powerful men and beautiful women. 
In the second level fantasy, Diane's id and ego are controlled by her superego. Diane rejects those qualities that she perceives make her submissive and incompetent. She fantasizes herself as Betty, who is fresh and attractive. She becomes a Canadian, a sign of naiveté, and takes on Anglo upper-class manners. In this fantasy world, Betty is in charge. Camille, now turned into Rita, is denied her superior identity. Her memory is completely gone; with her life under threat, a new noir gangster subplot results in the punishment of the director who flirted with her in the first fantasy. A chart of this transformation will be helpful at this point:

$\begin{array}{llll}\text { Diane (S2-RF/F1) } & \text { Betty (S2-F2) } & \text { Camille (S2-F1) } & \text { Rita (S1-F2) } \\ \text { American } & \text { Canadian } & \text { Mexican } & \text { Mexican } \\ \text { adulterated } & \text { naive } & \text { femme fatale } & \text { no identity } \\ \text { controlled } & \text { in charge } & \text { manipulative } & \text { controlled } \\ \text { hazel } & \text { blonde } & \text { brunette } & \text { brunette } \\ \text { child } & & & \text { mother }\end{array}$

In the first fantasy (S2-F1) Camille is Diane's object of desire. To have her completely, Diane creates a second level of fantasy, like a dream within a dream (S1-F2). While doing that she represses her identity as Diane to the unconscious, which leads to the breakdown of her first fantasy because she was too much herself. Thus, the unresolved conflicts between her unconscious inclinations and repressive demands of the ego resurface in the second segment of the film as the very first fantasy (as if waking up from the dream-within-a-dream). A new self, 
Betty, is created by repressing Diane. The new self becomes a stranger within; a strange feeling of doubleness/duality exists when we see Betty of S1 as Diane in S2.

Diane's fantasy structure operates by displacing an unacceptable element (incompetence, weak personality) onto the acceptable images of success and beauty. This process of fantasizing condenses different but related elements into Betty's image. In this way, Diane turns drives into their opposites to elude censorship. The vulgar and mean Diane becomes the naive and polite Betty.

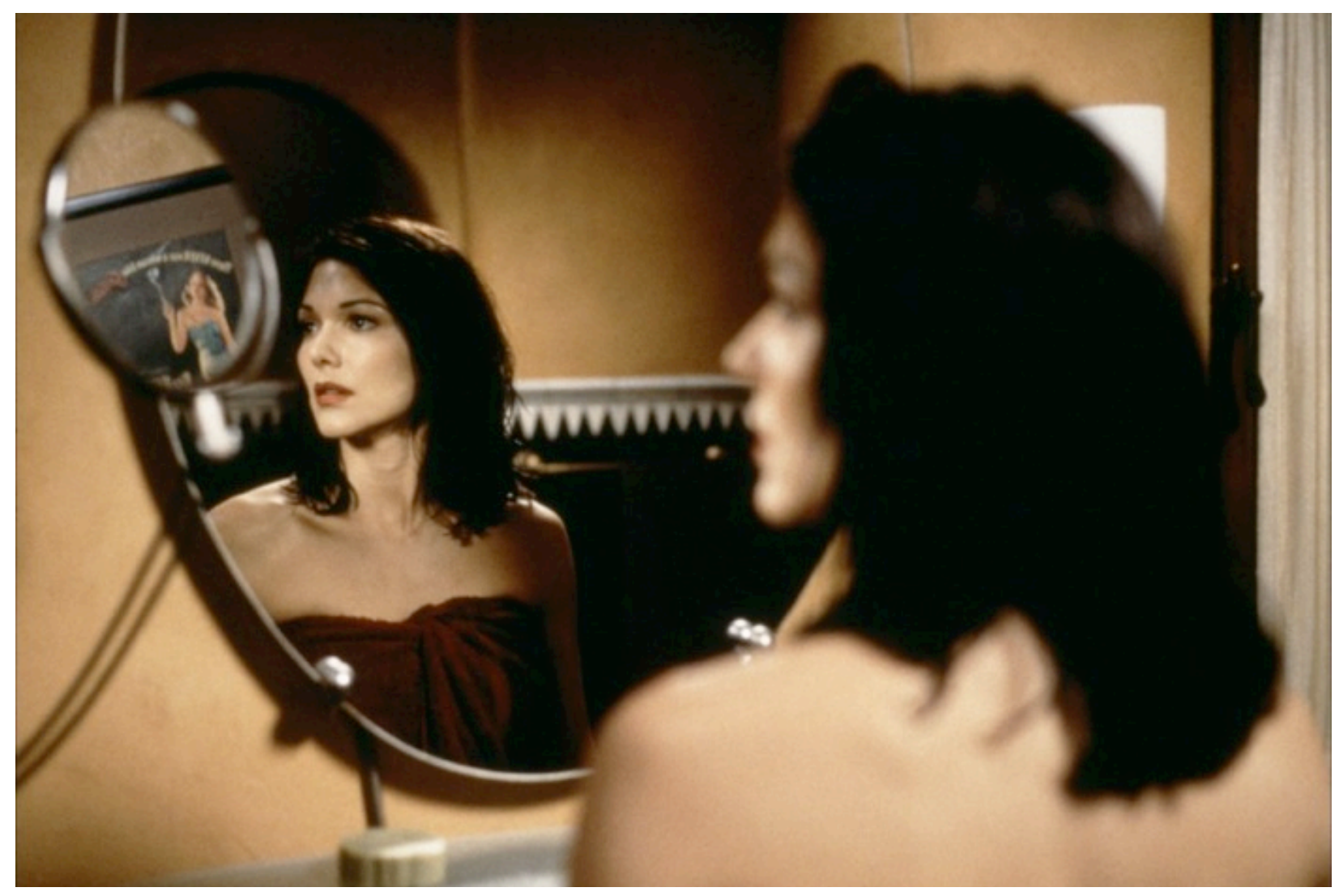

Figure 2: Camille looks at Gilda poster. Two characters mirror each other continously.

\section{Switching Identities: Reflection and Introjection}

The identity switch of Diane-Betty and Camilla-Rita can be explained through the Freudian concepts of fixation, splitting, introjection and projection. Reflection in psychology is a reflection of the unwanted aspects of the self to the other. Through the creation of a second layer fantasy in S1, Diane externalizes her own negative feelings by assigning them to someone else. She projects an unwanted aspect of her self, naiveté and easy manipulation, onto 
Rita in F2, freeing herself of the burden of being the loser in F1. In return, through introjection Diane shapes her new self as Betty by adapting a role model outside of herself. This leads to a splitting of the object of anxiety into two. Diane's personality is divided and her weak side in F1 is projected onto the Camilla of F1 to make her Rita of F2. This split translates itself metaphorically into a lock and a key. The key found in Rita's bag unlocks the blue box found in Betty's bag in El Silencio, the place of deep unconscious. When the key fits into this blue box, the second fantasy framework is broken and collapses into the first fantasy framework. This new narrative segment begins where we can now see Diane's true self as the space-time of the film is only once removed from its framework of reality.

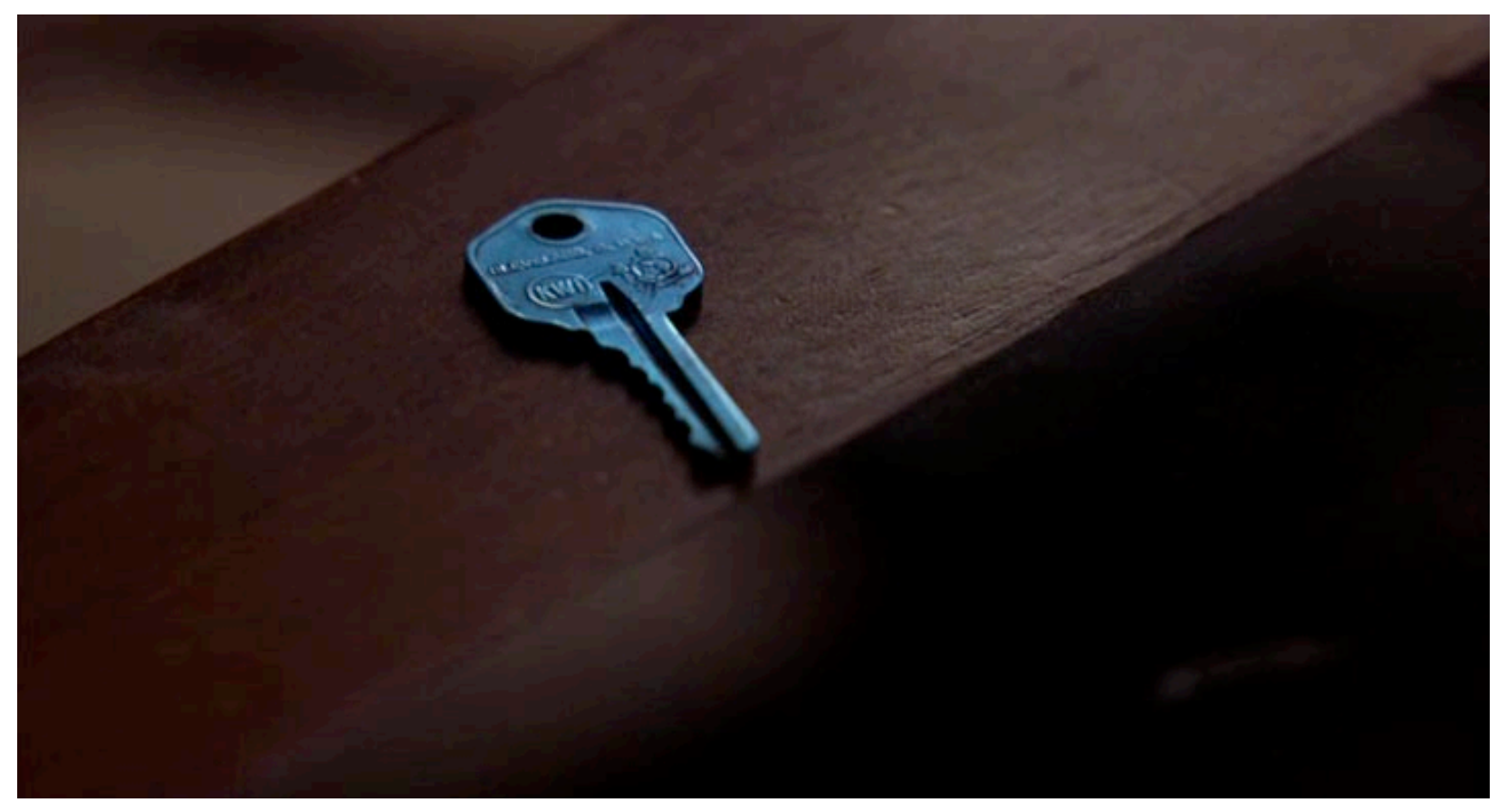

Figure 3: The key to Diane's fantasies lurks in from time to time.

In S1, Betty is Diane's premature naive self and has anxieties about entering into the adult world. This results in a fixation on a premature sexual part, the breast. As soon as Betty and Rita fall in love and have sex, they start touching each other's beasts, enjoying the experience. In S2, where we see Diane having sex with Camille, they try to engage in genital pleasure but Camille is extremely disturbed by this, just like masturbation, which gives a shock like a blurring of reality and fantasy in her vision. 
Heterosexual encounters are also fantasized as being punishing experiences. In an interesting and complex narrative in S1-F2, Betty is invited to an audition to play a young woman in love with her father's friend. Betty's casting agent brings her to a room where the producer, the director and lead actor of the film (all male) are holding auditions for the lead female role of a film. When the lines of the dialogue are practiced by Betty and Rita prior to the audition, they sound funny, as a dialogue that would not be suitable for two women. During the audition, Betty and the older actor (a father figure) begin reacting to each other's moves. The scene comes to life as it becomes a passionate heterosexual scene where Betty, a young childish woman (daughter), seduces an old man (father) and pushes him to have sex with her (incest). The aroused actor is surprised and is in pain, unable to finalize the sex act in real life. This is yet another punishment of men in Diane's second fantasy.

The narrative complexity is highlighted when we, as the audience, watch this audition inside of the reality frame of the audition (RF-4). As Diane transforms herself from a loser in F1 into a seductive talented actress in F2, we experience five reality frames. When we watch the scene in a close-up, it creates a fourth and a deeper level of reality frame of that fictive scene in a fantasy world created by a fantasizing Diane (and us, the audience, watching a fictional account of events in a movie theatre) sitting on her bed. The eeriness of the scene increases when we begin to suspect the simplicity of the audition process (where the director sits in a chair, looking blank, and the actor and the producer stand up and wait for people to come); this creates a feeling like a fake audition carried out by the casting agent to test Betty's talent. Obviously, in this secondary fantasy, Diane wants a quick and simple way to attain celebrity status. The reality frames of this scene can be schematized as follows:

Our reality as viewer

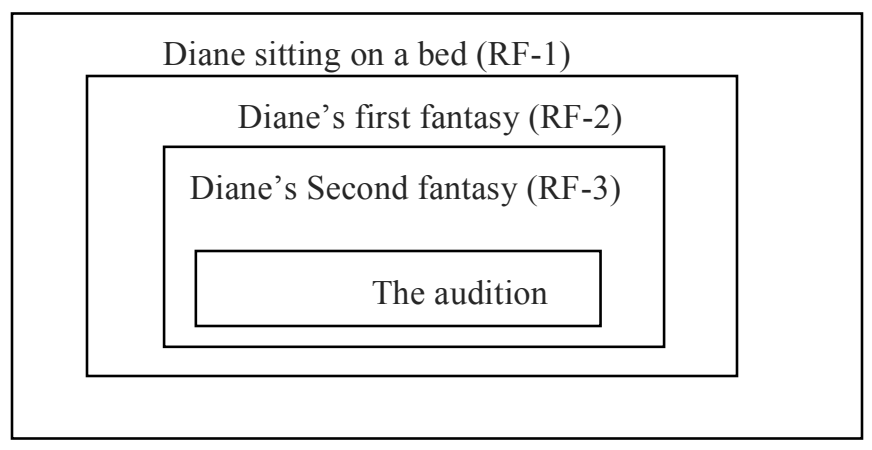

The audition scene connects Betty to Diane as Diane's unconscious begins to come back as a result of pushing the limits of her fantasy. Adam, the director, has to cast a new actress because his lead actress is not lost (that's Rita, a punished Camille from Betty's first fantasy). Adam's punishment is to cast someone else, Camilla Rhodes, a 
blonde woman who was forced upon him by the mob. Since all of this was a fantasy created by Diane, the two fantasies conflict. The need to punish those who hurt her in the F1 conflicts with her desire to become a successful actress. So an illogical step is taken and Betty quits the audition to check upon Rita who is waiting for her at home. Before she leaves the audition, Betty and Adam briefly come eye to eye, in a strange an unexplainable sexual encounter. Signs of hesitation and wonder appear in Adam's eyes. This may be the moment when Adam may prefer to cast Betty over Camilla, thus risking his life in the process. Diane's fantasy is at its peak point. As Betty she has the ability to seduce the director in her first fantasy, and empowered this way she can prefer to leave and audition of a lifetime for her lover, Rita.

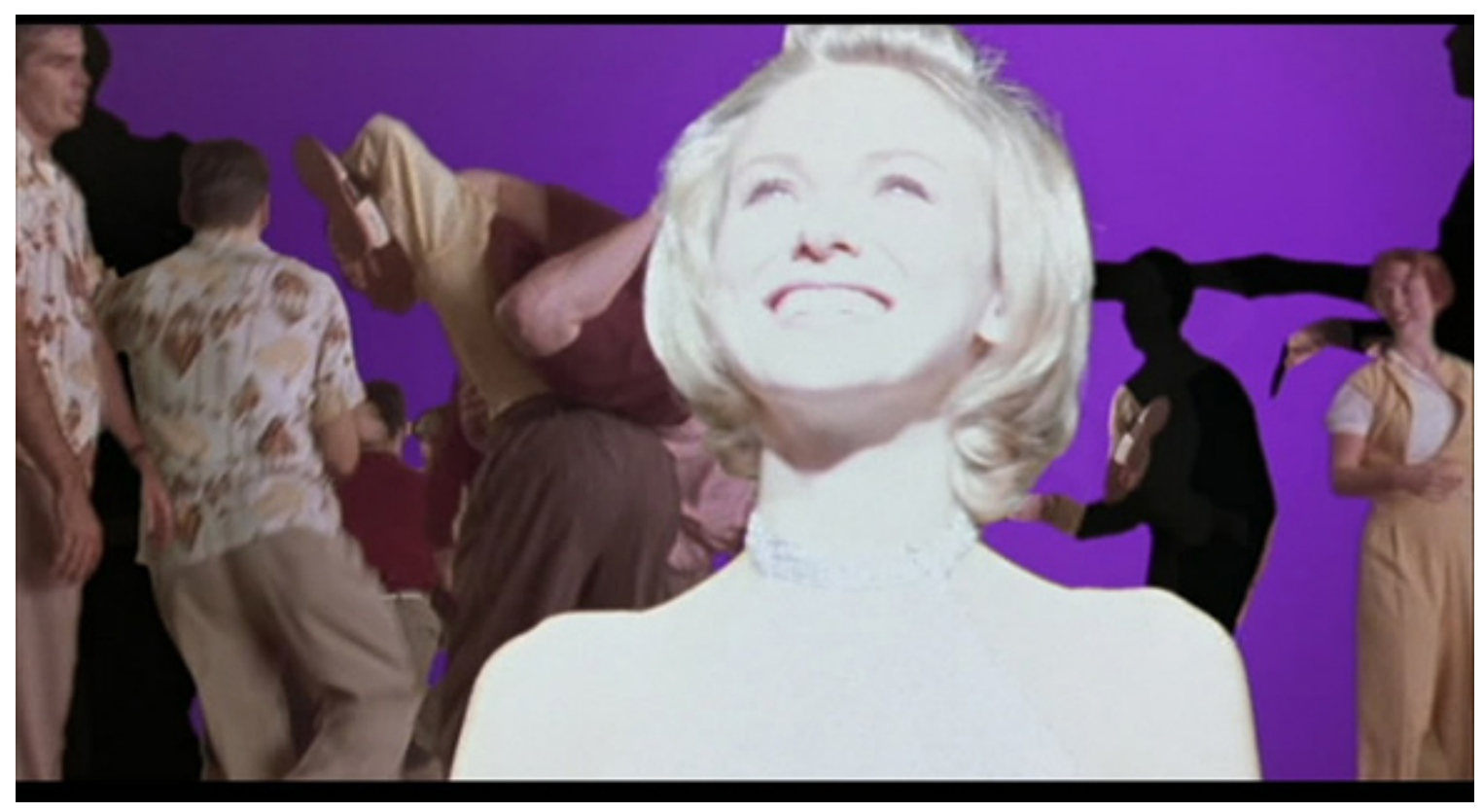

Figure 4: Play of fantasies in the opening of Mulholland Drive.

\section{Psychosis and Schizophrenia}

What Diane did not have in mind was that she thought she could control two layers of her fantasy at the same time but infact she cannot. When her ego fails, her unconscious takes over the conscious and control breaks down altogether in Diane's real life. The content of Diane's first fantasy is expressed directly without mediation by the conscious after Diane's second fantasy breaks down. Diane's first fantasy is also shattered as she comes in and out of it near the end, seeing her imaginary aunt and uncle as little demons sneaking under her door. 
The initial point of disturbance that leads to Diane's psychosis is when she fantasizes that she is dead in S1. As Betty and Rita search for Rita's identity, they come across a waitress whose nametag is Diane, an unconscious reminder to a fantasizing Diane of her true self. Not surprisingly, in all of L.A. there is only one Diane Sullivan they find in the phone directory. This Diane Sullivan lives in an apartment complex not so different from the one in which Betty lives. Betty and Rita meet the very same housemate/lover in Diane's real life. After entering Diane's house they discover her dead and stinking body (death wish). This very corpse belongs to Diane herself, who is fantasizing in the very same bed. Diane's unconscious surfaces in her real life as she mentally breaks down and shoots herself. In her first fantasy, he hires a man and gives him Camille's photo so that he can either kidnap her or kill her, but we never know which.

Some objects appear as symbols that remind us of these fantasies, such as the black ringing phone that reappears in Diane's apartment. The coffee mug is first used to reference to Castigliani brother in F2 it then reappears in a diner, Winkie's, where two men talk about their dreams, and finally again in Diane's house in F1. The ashtray belonging to Diane's former housemate/lover reappears in the end of the film to signal that Diane is fantasizing.

In a similar manner, the characters and places from Diane's first fantasy reappear with differing roles in fantasy two. In F1 Adam's mother Coco becomes Betty's landlady in F2. The cowboy who happens to pass by in Adam's party in F1 becomes his nightmare in F2. The glamour girl who kisses Camille in F1 becomes Camille, the mob girl, in F2. The man who pays the bill in F1 becomes an obsessed man who is shocked by his dreams in F2. This man is another clue to Diane that her fantasy world is collapsing. The man having breakfast with his friend in a diner talks about a scary dream and mentions that it seemed to be controlled by someone outside. In addition, the street signs do not match throughout the film. In F2 Rita comes to Sunset Boulevard whereas Rita orders the cabby to go to 1612 Havenhurst, stripping Diane's fantasy of consistency. In El Silencio we are reminded by the presenter that all is illusion. This comment signals to us and Diane that we are experiencing someone else's fantasy. 


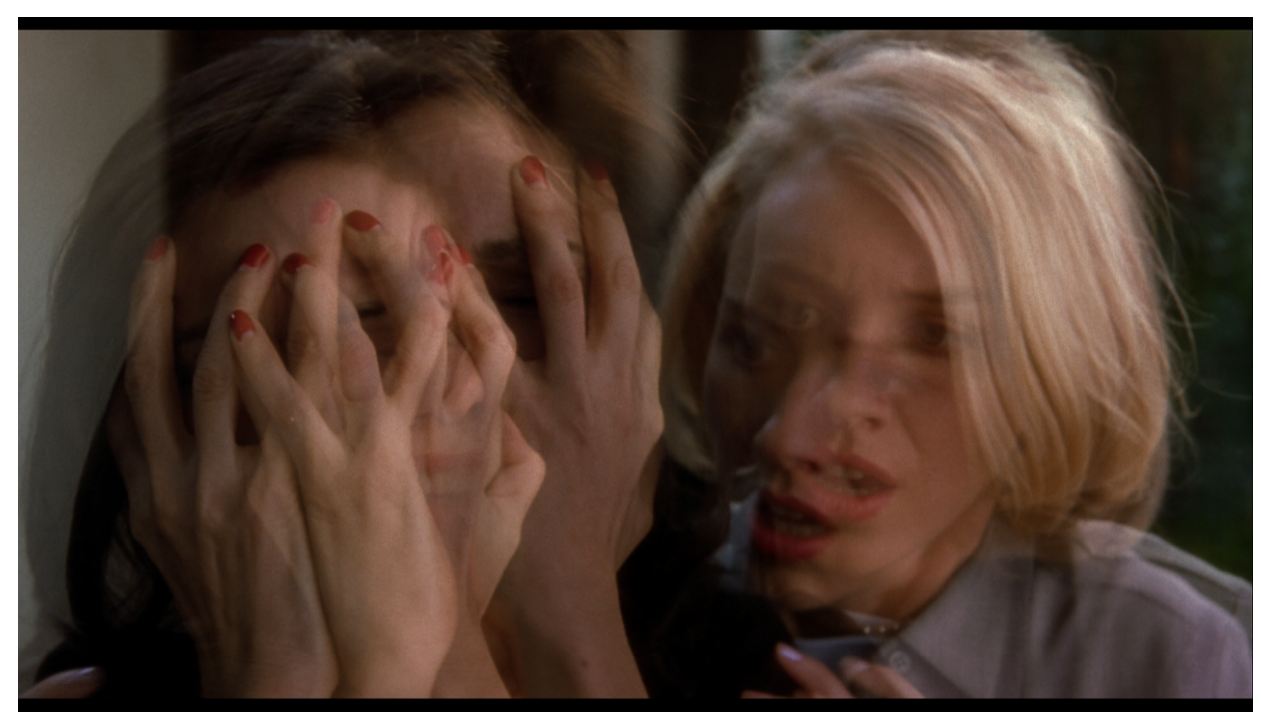

Figure 5: Reality collapses on Diane's fantasy as Camille and Betty clash into each other.

\section{Where Lacan Comes In}

The three major Lacanian concepts are the Real, the Imaginary and the Symbolic. The Real is the realm of impossible enjoyment, the Symbolic refers to the symbolic order of language and communication, and the Imaginary is the domain of images with which we identify (Zizek 2000: 9).

In Mulholland Drive, Diane is neither happy with her reality nor with her first fantasy. Thus she fantasizes herself as Betty, creating her own Real. She changes her symbolic order by becoming a blonde, upper-class Canadian woman in her imaginary (fantasy). In F2 Betty does not hesitate to follow the symbolic order of society. She seduces men in auditions and flirts with people to get her role. Her social acts form her fantasmic identity. The mirroring process mentioned often in Lacan's works goes to such a level that Diane's projection of Rita later becomes Betty when she puts on a blonde wig. In F2, the desire for the other is twofold. Diane both desires to be like Camilla of F1 and wants to satisfy Rita's needs in F2 (just like the Lacanian child looking at the mirror and thinking that her reflection is her mother). Because these are fantasmic creations, Diane can know neither Camille's (F1) nor Rita's (F2) innermost desires, and she projects her own desires on Rita, such as the need for protection. In this way, Betty's choice to go back home to Rita instead of attending the audition of a lifetime conflicts in Diane's mind, as she is fantasizing both for herself and a fantasized Diane in F1 at the same time. The 
opposition between the obscene superego in Diane's second fantasy conflicts with the Symbolic Law in her first fantasy. The impossible Real conflicts as Betty's fantasy world mixes with Diane's unconscious.

As Diane's barred subjectivity finds its big Other in Camille in F1, she places herself in this symbolic order by introjection and projection in F2. For Lacan, ego is constructed through imaginary percepts and narcissistic fantasies (Rivkin and Ryan 1998: 123). Diane forms a false narcissistic unity with Camilla in F1 and brings out Betty as the narcissistic self in F2. This narcissism finds its ultimate expression when Betty takes Rita to bed, looks directly at her (as if to a mirror) and says: "I am in love with you." Diane's sense of reality has a connection with objects in the creation of a new self. Her mirror becomes Rita. The two also have a relationship that resembles that of a mother and a child. These roles are reversed in Diane's first fantasy. In F2 Rita is like a helpless child and a very assertive Betty is in charge of her needs like a mother. In F1, Diane is the child dependent on Camilla. During this identification with the mother in F2, Betty reaches fulfillment through the breast, as discussed above as regards this particular tenderness between Betty and Rita when they touch each other's breasts.

The fissure, an opening into the reality (beance) is realized through the blue box in Betty's pocket. This is the object petit $a$, the object of desire caught up in the unrealizable search for the eternally lost pleasure (Stam 1992: 127). By assuming her other's identity in this stage, Diane tries to reach the Real, an impossible wholeness of the self. Thus the jump from F1 to F2 is joussance, the place of obsession where Diane enjoys the Real enjoyment as Betty. But since this is impossible to attain in reality, her fantasy world implodes into itself.

\section{Oedipal Triad: Adam, His Wife, Her Lover and the Cowboy}

In F2, Adam is the most severely punished person in Diane's fantasy, possibly for stealing Camilla from Diane in F1 (along with Camille herself trying to escape from hitmen and losing her memory in this fantasy). The relationship between the film director, Adam Kesher, his wife, her lover and the mafia is very interesting in Freudian terms. In F2, Adam shows signs of an Oedipal complex with everyone around him. He shows the neurotic symptoms of love and jealousy for his wife in F2, which is his punishment for flirting with Camille in F1. When Adam catches his wife and her lover in their own bed, he does not see remorse in them. Instead, the two treat him as a child who interrupts his parent's lovemaking. The lover even beats Adam for interfering in their 
privacy. In this Oedipal triad, Adam, whose name suggests the very first man on earth, is the child who is in love with his wife (mother) but cannot have sex with her. He is punished by the love (father) that beats him (castration anxiety).

Another aspect of this is his phallic extension, a golf club. Adam takes his golf club wherever he goes, even to the meeting with film producer. After he experiences his first major threat (the mafia boss), he goes out and shatters the windshield of mafia boss' limousine. This phallic object is extension of Adam's virility as well, until he leaves it at home and gets a beating.

Adam also compromises after the more masculine threat of an eternal father, the mafia boss, which results in his temporary loss of money and influence. Adam's desire to control people (make films), have sex (with lead actresses) and have expensive cars are repressions of the unconscious, forcing him to compromise. Adam's castration anxiety is personified as the Cowboy figure in Mulholland Drive. This cowboy mysteriously contacts him and warns him about hiring Camille Rhodes. It is important to note that the cowboy makes Adam repeat the words: "I know what I want" which signifies an internal psychic dilemma Adam is facing with the cowboy as the ultimate American male ego-ideal ${ }^{4}$.

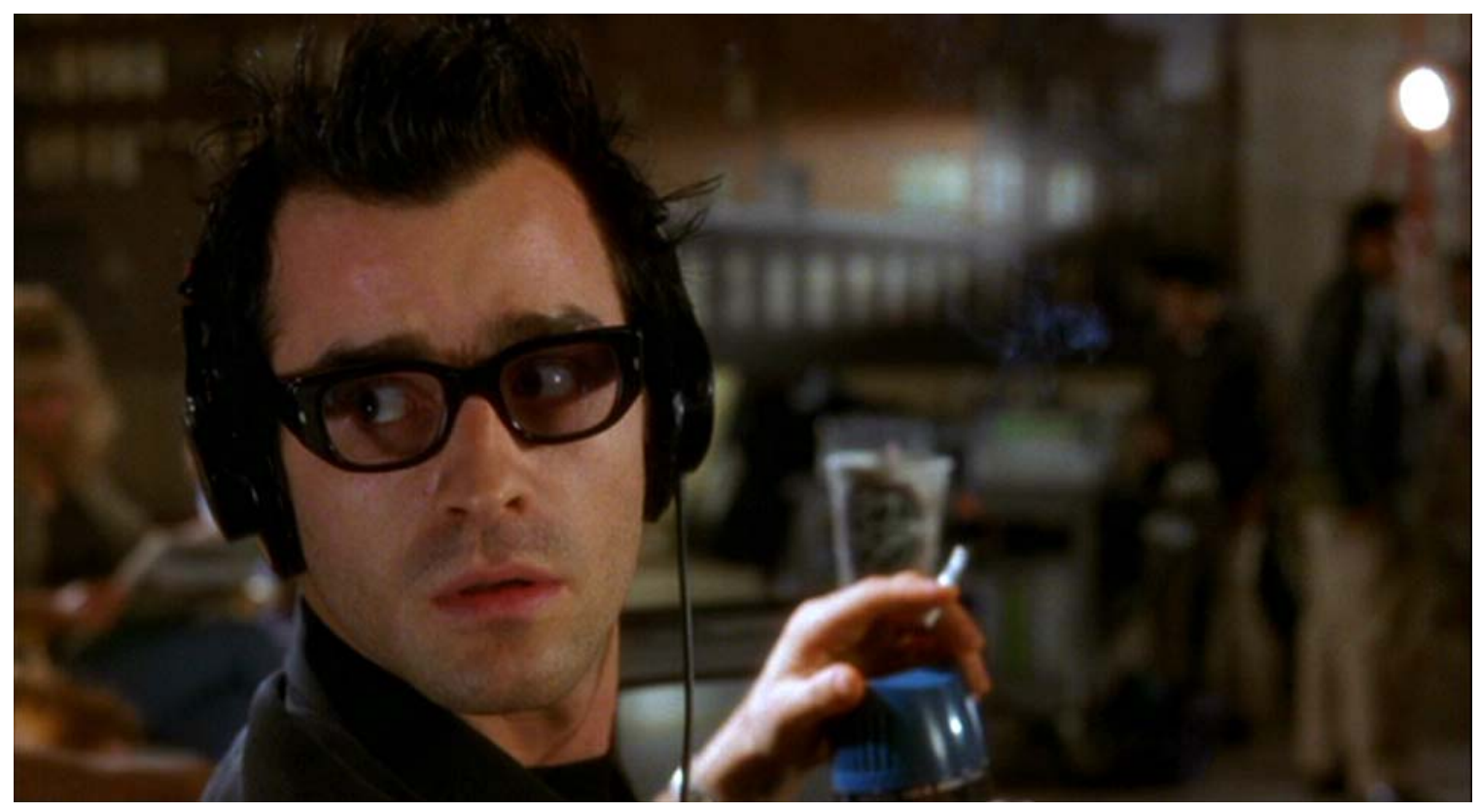

Figure 6: Adam (Justin Theroux), the film director in Diane's fantasy, is under constant threat from 'the father'. 
The big boss (Mr. Roque) is ironically a midget sitting silently in a wheel chair in darkness behind a glass panel. He never speaks and people come to report to him. Mr. Roque controls the two hitmen brothers and can watch anything related to him though a device on the wall like an omniscient God. This is Diane's fantasy of a silent patriarch who can control Adam's life. In Lacanian terms, Mr. Roque is pere joissance who represents the paternal law. The creation of such a powerful external fantasy element can only satisfy Diane's loss of lead roles in the films she wants to act in both in F1 and F2.

\section{The Metapsychology of a Meta-Narrative: A Conclusion}

If we were to explain the metapsychology of Mulholland Drive, we could say that the reading of this film requires a combination of the dynamic, economic and topographical aspects of Freudian analysis (Stam 1992:124). It has to be dynamic because of the psychic phenomena, the conflict of instinctual forces that lead to Diane's fantasies. It has to be topographical because physical space is divided in terms of systems (unconscious, preconscious, and conscious) and agencies (id, ego, superego) to the point that fantasies are built on top of fantasies that blur reality and later implode. Diane brings her repressed psychic-mental material to a consciously constructed fantasy. She tries to build a resistance to her disturbing reality by reaching out to her subconscious. A new subjectivity is formed in a new discourse (of this film) of sounds, voices, pictures, and stories. This is framed by Lynch as a new discourse within the film medium where we deal with a split subject and object petit a. In addition to her lesbian fantasies, Diane also imagines Adam and mafia as the representation of male sexual and Oedipal anxieties. Both fantasy frames end in failure and the destruction of their creator. Betty disappears suddenly at the end of S1-F2 and Rita disappears alongside with her after she opens the blue box, unlocking the fantasy. The Diane of S2-F1 also loses her sanity and possibly it is this going in and out of two the fantasies drives the real Diane to commit suicide.

Mulholland Drive is indeed a very complex film with a complicated premise. It includes different sets of people in different narrative segments and fantasies with interesting relationships between couples (Betty-Rita, DianeCamilla, Adam-cowboy-mafia, waitress-hitmen-detectives) that allows for different types of approaches other than psychoanalysis. Yet the psychoanalytic elements form the foundation of the fantasies that find their visual representation as this film. The application of Freudian and Lacanian concepts to the work of Lynch in general provides us with a better understanding of what Lynch's cinema is all about.

CINEJ Cinema Journal: Memory, Identity and Desire: A Psychoanalytic Reading of Lynch's Mulholland Drive 


\section{ENDNOTES:}

${ }^{1}$ I would like to thanks Mark Wyers for his proofreading the text.

2 Johnny Mnemonic, Dark City (Alex Proyas 1998), Gattaca, The Sixth Day, AI (Steven Spielberg 2001), Impostor (Gary Fleder 2002), Minority Report (Steven Spielberg 2002) are sci-fi films interested in artificial construction of identity through cloning, gene and cybernetic technology. Some films were also interested in how spaces define who we are such as Century Hotel. There is also an increasing interest in films dealing with the fear of the repressed and unknown such as The Cell (Tarsem 2001), The Others (Alejandro Amenabar 2001), The Haunting (Jan de Bont, 1999), House on the Haunted Hill, Blair Witch Project, Sixth Sense, Bless the Child, Stir of Echoes, Stigmata, Lost Souls, The Mothman Prophecies (Mark Pellington, 2002), Glass House, 13 Ghosts, Jeepers Creepers, Resident Evil, The Devil's Backbone.

${ }^{3}$ This author has previously critiqued Zizek's approach for being too committed to Lacanian terms to the extent that it misses the point (Akser, 2002).

${ }^{4}$ It is important to note that the appearance of several storylines and characters such as Dam's cannot only be explained as Diane's fantasy. Adam may be existing in multiple narratives and fantasizes as well as being part of an elaborate deeper level fantasy of Diane. This reviewer accepts that it is difficult to explain the theft of a black book and accidents related to it in Mulholland Drive.

\section{REFERENCES:}

Akser, M. (2011) Reinvigorating film studies: an immodest proposal. Cinej, 1:1, 1-3. doi: 10.5195/cinej.2011.26

Akser, M. (2002). Review: slavoj zizek: the fright of real tears: krzysztof Kieslowski between theory and posttheory. Canadian Journal of Film Studies, 11:1, 108-111.

Allen, R. (1999). Psychoanalytic film theory. In R. Stam and T. Miller (Eds) A companion to film theory (pp. 123145). Oxford: Blackwell.

Bergstrom, J. (1999). Endless night: cinema and psychoanalysis, parallel histories. Berkeley: University of California Press.

Cook, P. (2008). The cinema book $3^{\text {rd }}$ ed. London: BFI. 
Cook, R.F. (2011). Hollywood narrative and the play of fantasy: david lynch's mulholland drive. Quarterly Review of Film and Video, 28:5, 369-381. doi:10.1080/10509200902820647

Hotz-Davies, I. and Kirchhofer, A. (Eds.) (2000). Psychoanalytic-ism: uses of psychoanalysis in novels, poems, plays and films. Trier: WVT.

Kaplan, E. A. (Ed.) (1990). Psychoanalysis \& cinema, New York: Routledge.

Lacan, J. (1979). Four fundamental principles of psychoanalysis. New York: Norton.

Lacan, J. (2007). Ecrits: a selection. tr. Alan Sheridan, New York: W.W.Norton \& Company.

Lebeau, V. (1995). Lost angels: psychoanalysis and cinema. London: Routledge.

Lentzner, J. R. and Ross, D. R. (2005). The dreams that blister sleep: latent content and cinematic form in mulholland drive. American Imago, 62:1, 101-123. doi:10.1353/aim.2005.0016

Love, H. (2004). Spectacular failure: the figure of the lesbian in mulholland drive. New Literary History, 35:1, 117132. doi: $10.1353 / \mathrm{nlh} .2004 .0021$

McGowan, T. (2004). Lost on mulholland drive: Navigating david lynch's panegyric to hollywood. Cinema Journal, 43:2, 67-89. doi: 10.1353/cj.2004.0008

Rivkin, J. \& Ryan, M. (Eds.). (1998). Literary theory: An anthology, Oxford: Blackwell.

Stam, R. (2000). Film theory: an introduction. Oxford: Blackwell.

Stam, R. and Miller, T. (Eds.). (2000). Film and theory: An anthology. Oxford: Blackwell.

Stam, R. and Miller, T. (Eds.). (1999). A companion to film theory. Oxford: Blackwell. 
Stam, R., Burgoyne, R. \& Flitterman-Lewis, S. (Eds.). (1992). New vocabularies in film semiotics: structuralism, post-structuralism and beyond. New York: Routledge.

Tubrett, D. (2001) 'So where are you?' On memento, memory, and the sincerity of self-deception. Cineaction, 56, 2-10.

Tüzün, D. (2012). Abject's "ideal" kin: the sublime. In G.B. Pierce (Ed.), The sublime today: contemporary readings in the aesthetic (pp. 119-142). Newcastle upon Tyne: Cambridge Scholars.

Zizek, S. (2002). The fright of real tears: krzysztof kieslowski between theory and post-theory, London: BFI.

Zizek, S. (2001) Enjoy your symptom!: jacques lacan in hollywood and out $2^{\text {nd }}$ ed. New York: Routledge.

Zizek, S. (2000). The art of the ridiculous sublime: on david lynch's lost highway. Seattle: University of Washington Press.

Zizek, S. (1992). Everything you always wanted to know about lacan...but were afraid to ask hitchcock, London: Verso.

Zizek, S. (1991). Looking awry: an introduction to jacques lacan through popular culture. Cambridge, MA: The MIT Press. 